\title{
Dividualisation and relational authorship: from the Huguenot République des lettres to practices of clandestine writing
}

\section{Complementary questions}

Relational authorship has recently been discussed in the contexts of literary studies and of the history of knowledge. ${ }^{1}$ I would like here to bring these discussions together with another concept: that of dividuality. While relational authorship looks at the collaboration of different authors or actors in the creation of a single work, the theory of dividuality is concerned in particular with the division of a single author into distinct personae, which manifest themselves in different works, or indeed within a single complex text. On the one hand, a work which emerges from a network; on the other, a network in a sense within an author, or the author as a networked plurality. Each of these would seem to be a case for a social epistemology - at least where the works in question deal with aspects of knowledge - but the question arises: what is the relation between these two things? Are they complementary phenomena? Or are the questions and perspectives arising from these two approaches quite different to each other? This is what I want to examine here.

In doing so I will in fact look at texts that deal with knowledge, specifically texts which are largely philosophical and theological, and I will concentrate on the period around 1700. My approach to the Enlightenment will therefore take in a 'long' 18th century, which had already begun in the debates, often in French, from the 1670s onwards, with Simon, Le Clerc, Bayle, van Dale and Fontenelle. ${ }^{2}$

The Enlightenment developed not least out of theological disputes and debates critical of religion, and as the names mentioned here suggest, Huguenot thinkers were at the centre of the fray (Haase 1959). It may therefore be legitimate to focus on these writers, at least at the outset of this investigation. In a later

1 See e.g. the conferences organized by Carlos Spoerhase and Erika Thomalla, 'Werke im Netzwerk. Relationale Autorschaft im 18. Jahrhundert', held in Berlin, 11-12.5.2017, and Bielefeld, 16-18.11.2017.

2 See the still classical work by Hazard 2013, but also Israel 2001.

Note: Translated from German by David Finch.

2 Open Access. (C) 2019 Martin Mulsow, published by De Gruyter. (ल) BY-NC-ND This work is licensed under a Creative Commons Attribution-NonCommercial-NoDerivatives 4.0 International License. https://doi.org/10.1515/9783110580853-023 
part of this essay I will then make the transition, as seamlessly as possible, from instances of dividualisation to questions of relational authorship. I will consider the theoretical implications of a social epistemology of authorship throughout this essay, and especially towards the end.

\section{Dialogised theology}

As has been said, the most sophisticated combatants of the early modern République des lettres were Huguenots; their experience of emigration, especially after 1685 , made them international in outlook, militant and quick to respond to new intellectual currents. The plurality of the situation, in terms of Cartesianism, Spinozism, Lockean empiricism, chiliasm, Socinianism and critical studies of the Bible, led - I suggest - to a 'dialogised' form of writing, and even to a splitting of authorial personae.

As is well known, the idea of 'dialogism' was introduced into literary theory by Mikhail Bakhtin, to address the 'polyphony' found in many novels of the modern era, from Rabelais to Dostoevsky (Bakhtin 1984). The concept has since become almost a commonplace - in contrast to the monological world of the Middle Ages, in which a single world view was largely predominant, Bakhtin sees in the 'open Galileian world of many languages, mutually animating each other' and of competing world views, a dialogism expressed in ambivalent and hybrid forms of language and in the linguistic variety of the characters. There arises in the novel an 'interaction between different contexts, different standpoints, different horizons, different expressive systems of emphasis, different social languages' (Mair 2015, 578f.).

The starkness of the opposition here between the medieval and the modern has been often criticised, but for the moment we will let it pass. More important, it seems to me, is the productive use Klaus W. Hempfer has made of this view for our understanding of the Renaissance dialogue (e.g. Hempfer 2002), a use that was not at the forefront of Bakhtin's thinking (as his understanding of dialogism was not primarily that of the direct disposition of language in the dialogue form). But this approach brings new aspects to the fore, especially where the language of knowledge, of science and the humanities, is concerned: the Renaissance dialogue often addresses typical humanistic themes such as morality, politics and history, but also metaphysics and the philosophy of nature. If polyphony occurs here, one would conjecture that it is a direct reflection of the pluralised worldview of the early modern period (Mulsow 2000; Müller, Österreicher and Vollhardt 2010). These dialogues set out competing viewpoints in the form of arguments, not without some rhetorical flourishes. What they also demonstrate 
however is that in the 15th or 16th century it was not yet possible to give open expression to all competing viewpoints. While writers such as Lorenzo Valla or Poggio Bracciolini could present an Epicurean or a proponent of a free monetary economy as a figure within a dialogue, they were not free to identify openly with these positions (e.g. Schmitz 2004). Whether and to what extent real social networks and circles of debate were behind these dialogues, is a question I wish to, and must, leave open here. I want only to stress that the reader was left to draw his or her own conclusions, while the author disclaimed all liability, as a neutral moderator between divergent points of view (Mulsow 2007, 102-7). Renaissance dialogues therefore reflect on the one hand the beginnings of pluralisation, and on the other, concealed speech in an unfree context.

A field long closed to this form of dialogue was of course that of theology. Here no pluralisation was allowed - on the contrary, following the de facto pluralisation of the Reformation, which was experienced by some as a catastrophe, the different denominations were all the more concerned to ensure that dogmatic monologicity prevailed within their spheres of influence. But the new and urgent discussions of theological and exegetical questions, reinforced by critical philology, could not be stopped (see e.g. Van Miert et al. 2017). This is particularly clear in two cases, which touch on the area of clandestine literature: of texts which could only be distributed in manuscript copies, or which were printed in small numbers and kept hidden from the general public.

The first of these is well known - Jean Bodin's Colloquium heptaplomeres, from 1596 (Bodin 1857; see Gawlick and Niewöhner 1996). The author is not identified by name in the text, which can be ascribed to the famous political theorist only by means of internal evidence. The text itself puts forward no identifiable and unequivocal position, rather, as the title tells us, it gives us a conversation between seven speakers: a Catholic, a Lutheran, a Calvinist, a Jew, a Muslim and two non-confessional figures, one of whom appears to be a kind of Deist, the other a kind of sceptical Naturalist. The exchange between these figures purports to promote tolerance, but some of the arguments of the last two figures are critical of religion and open to a reading that leads to more radical conclusions, conclusions that deny the continued justification of Christianity.

Much less well-known is a dialogue by Christian Francken from 1593, between a theologian and a philosopher. Francken was one of the many religious seekers after truth of the 16th century; he began as a Catholic and a Jesuit, became a Lutheran, slid from there to Antitrinitarianism and went to Poland. He later moved to Siebenbürgen, where the nonadorantist strain of Antitrinitarianism was in the ascendancy. And, from being an Antitrinitarian, Francken eventually - at least possibly - became an atheist. That is the case at any rate if he identified with the position of the sceptical-atheistic philosopher in his Disputatio inter theologum et 
philosophum de incertitudine religionis Christianae. As with Bodin, this is not unequivocal. Francken leaves the question open, but the possibility of his atheism remains strong (Francken 1593; see Simon 2008).

I would therefore say that both Bodin and Francken are early cases of philosophical-theological dialogism. They remained exceptional for the moment, but by the second half of the 17th century at the latest, the epistemic situation had become so complex that dialogistic forms of writing took hold in theology, absorbing and expressing a polyphony of viewpoints.

This can be seen first, and even before the Revocation of the Edict of Nantes, at the Calvinist Academy of Saumur, where theological and classical studies were pursued in the tradition of Duplessis Mornay, Moyse Amyraut and Louis Cappel (Kretzer 1975). In 1674 at Saumur, Tanneguy Le Febvre, in his Epistolae, was the first to discuss philological questions in the form of a fictional exchange of letters (Ribard 2008). In 1681 the Arminian theology student at Saumur, Jean Le Clerc, took this as a model and, in his pseudonymous Epistolae theologicae, used fictional correspondents to present a range of mutually relativising theological positions. ${ }^{3}$ These letters surely reflect actual discussions between students at Saumur, relating to sceptical views on the Trinity, Cartesian philosophy, and historical and philological Bible criticism - there may be a network of participants in the background here too - but the point I want to make is that they are practising a new form of hypothetical writing. ${ }^{4}$ The theory of relational authorship takes a close interest in letter-writing networks, and all the more so when a number of letters are combined to make up a book.

The frame of Epistolae theologicae is provided by an anonymous (fictional) editor who presents himself as a friend of the - pseudonymous - Liberius a Sancto Amore, whose name adorns the title page. According to this editor, the texts contained in the work originated as adversaria, as notes and observations made while reading, and were then formulated as letters. Many of the views have an experimental status, says the editor: they have been expressed in private conversation in order to test them out ('saepe se expertum in familiaribus confabulationibus') (Le Clerc 1681, praefatio).

The 'letters' published within this framework are all written by Liberius, but are addressed to different recipients. The first letter, from August 1679, is to a 'Firminius Parrhasius', and develops its argument on the premise that Christ is coeternal with God the Father. It tests out a theory of the hypostatic union of the two natures of Christ, which employs Cartesian concepts. But the letter which

3 On Le Clerc see Barnes 1938; Pitassi 1987.

4 In the followings paragraphs, I adapt passages from a previous essay: Mulsow 2005. 
follows undermines precisely the premise on which the first letter is based. This second letter purports to have been written on New Year's Eve 1678 to 'Ambrosius Theographus', but is further framed and distanced by being solely an account of a 'Ludovicus Solinus', a friend of Theographus' uncle, who conducts a discussion, or comparison of views (a collatio), with two of his nephews, to whom he poses certain questions. This 'Solinus' is introduced as someone who has had to leave his home country and now resides elsewhere. It is almost as if one were being asked to see him as one of the Socinians who had been driven out of Poland. In any case, cultural transfer is built into this framing. The discussion between Solinus and his nephews is nothing less than a theological experiment in vivo: far removed from all theological debates, Solinus has instructed both nephews in Hebrew, Greek and Latin and then set them to read the Bible without any commentary. For three years they have studied entirely separately from each other. The question Solinus now poses is: what standpoint do they take on the question of the Trinity? One arrives at the position of the Reformed Church, the other at that of the Socinians. A dispute between the two brings no solution, and three friends brought in to arbitrate cannot decide on a victor. ${ }^{5}$ The moral of the story is therefore that if Scripture is so equivocal and unclear on this matter, we must be prepared to tolerate different opinions, and thus also those of the Socinians. The relational authorship of the positions, which is to an extent built into the text, is equirelational - the Reformed Church and Socinianism are equal in value. According to the Epistolae theologicae, the common ground in other questions - that God possesses all perfections, that He wishes to redeem mankind and that Christ died for this - suffices, alongside a shared morality, for a mutual acceptance.

The third letter, to a 'Coelius Optatianus', claims to have been written a little later, in February 1679. This Coelius has supposedly read Liberius' first two letters, at the home of 'Amicus'. Coelius wishes for a 'thorough explanation of the three modi of thought in the Godhead'. But Liberius must now admit to a difference in starting points in relation to his first letter. 'Before I had read the discussion, it was my view that the mystery of the Holy Trinity - which I assumed can be proved from Scripture - can be explained in this way, and I thought that it was therefore not necessary that I should write to my Solinus on this matter [...]' (Le Clerc 1681, 95f.). Now however, for Liberius, the given of the Scriptural guarantee of the Trinity is suddenly no longer secure. The rational reconstruction of the Trinity which follows has therefore a merely hypothetical character. This hypothetical doctrine presents a kind of psychological model of the Trinity:

5 On Socinianism and its relation to the Reformed Church see Daurgirdas 2016; Mulsow 2018, chapter 13. On the question of toleration, see Marshall 2006. 
'Although [God] is one, He can bring forth simultaneously any number of different sequences of thought, and therefore the persons in Him can be various. God thinking in a certain way is called the Father, in another way the Son, in another the Holy Spirit' (Le Clerc 1681, 103). These are therefore the 'modi cognoscendi' of the 'series cogitationum': the 'modus' of the Judge (the Father), of the Mediator (the Son) and of the Comforter (the Holy Spirit).

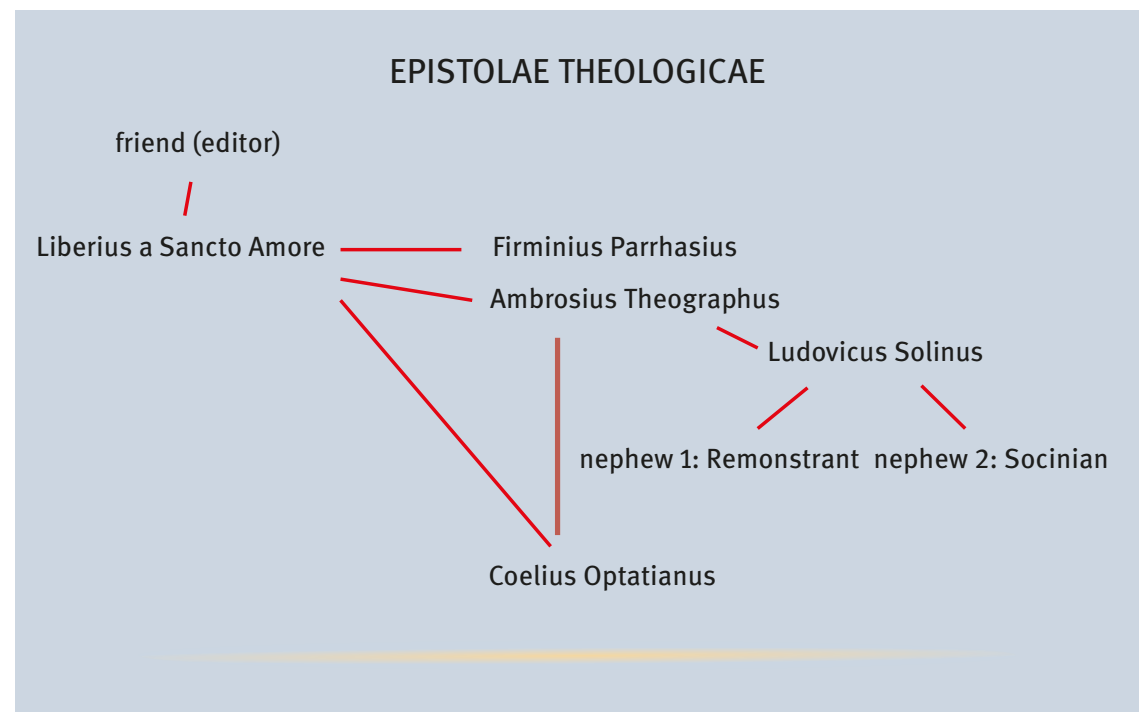

Liberius praises this theory - which is perhaps inspired by Spinoza's or Malebrache's terminology - as not open to the charge of Sabellianism (as in this modalistic view the persons are consecutive and not side by side), and sees it therefore as a possible alternative to Socinianism: this standpoint is 'as probable as the Socininian one' and is consistent with 'right reason'.

Hypothetical questions and considerations of probability are being weighed up here. The probabilism of the 17th century throws its shadows. If we examine more closely why Le Clerc in particular developed a dialogised form of this kind, we come upon the role of Erasmus of Rotterdam in this phase of the history of theology, and in this way the Renaissance dialogue is present once again. Le Clerc's great edition of 1703-1706 of the works of Erasmus is only the late and external sign of this effect. Erasmus stands, as Stefano Brogi has said, for the combination of philological exactitude, liberal reasoning and rhetorical finesse (Brogi 2012). Perhaps, following Pocock's 'Machiavellian moment', we can call this development of theological polyphony in texts by a single author the 'Erasmian moment'. 


\section{The pluralisation of masks}

When the Academy of Saumur was dissolved in 1685, complex argumentations, in which authors split themselves into a kaleidoscopic array of possible positions, were carried forward into exile, in particular in the Dutch Republic (Mulsow 2010). In 1687, Noel Aubert de Versé, a Socinian and friend of Le Clerc, presented in Le Tombeau du Socinianisme, - a merely ostensible refutation of Socinianism the fictional letters of a 'Basilius von Ankyra' to one 'Eudoxus'. In fact, the matter is even more complicated: the book is a seeming riposte to the Le Protestant pacifique by a Seigneur de la Guytonnière from 1684, a text which was in fact also written by Aubert de Versé. So the author is operating under different pseudonyms, playing them off against each other. ${ }^{6}$

Aubert de Versé is not an easy author to interpret, and was not, even for his contemporaries. He changes repeatedly back and forth between Protestantism and Catholicism; in Paris he collects his pension for reconversion but then returns to Holland. He is therefore greatly mistrusted by both sides. It is said that he will hire his pen to anyone who will pay him, and even his Protestant comrades in arms such as Pierre Bayle regard him with suspicion, despite the fact that he is in the forefront of the fight against Bayle's close personal enemy Pierre Jurieu.

The most consistent element in Aubert's writings is his Socinianism, or more precisely, his rejection of orthodox forms of the Trinity. This said, it seems to have been relatively unimportant to him whether he associated with liberal Catholics (with Gallicans and Oratorians), or with liberal Protestants. But as far as Socinianism was concerned, his writings show an attempt to bring together Arian positions, like those of his friend Christoph Sand, with Socinian viewpoints. At the same time, he brings these theological themes into contact with the new philosophical language of Cartesianism and Spinozism (Scribano 1988).

In this way, a game of deception and misdirection arises which is even more perplexing than Le Clerc's already confusing Epistolae theologicae. We can say of Aubert that the theological dialogism demonstrated by Le Clerc is extended throughout his entire intellectual life as an author, and that in the pseudonymous disputing personae of his writings and his changes of confession he embodies the multiplicity of viewpoints circulating at the time.

In his Le Tombeau du Socinianisme Aubert uses, like Le Clerc, patristicsounding names as cyphers for different hypothetical viewpoints. At the end of the book, he prints the already mentioned letter from one 'Basilius of Ankyra' to 'Eudoxus'. This 'Basilius' expresses a textually critical view of the Bible, as did

6 On Aubert de Versé, see Morman 1987. 
Le Clerc's 'Solinus'. 'Now to conclude this work', writes Aubert, 'I wish to include here a letter written to me by a friend, whom I shall call Basilius of Ankyra, on the subject of the Trinity [...]. Here we find a quite new hypothesis on the Prologue to the Gospel of St John, a view completely contrary to my own, but which so destroys my previous conception that I am seized by enthusiasm, and which on reflection compels me to say that this is not a hypothesis, but a truth which seems to me divinely inspired' (Aubert 1687, 169).

I cannot go into the detail of the theological discussion here, but it is probably clear that with Aubert, even more than with the dialogues of the Renaissance, a complex dialogism is at work. The author is torn this way and that between the diverse exegetical and dogmatic possibilities of thinking a doctrine of the Christian Trinity which no longer holds Christ to be co-original with the Father. He wants to give voice in his work to the ambivalence and indecision in relation to the possibilities, but at the same time he needs to give due consideration to a wide variety of interests, according to whether he wants to recommend himself to the Catholics or to the Protestants, whether he needs to camouflage his Antitrinitarianism as orthodox, or even, as he was forced to do in his later work Anti-Socin, to demonstrate the orthodoxy of his views by writing a retraction of his earlier works (Aubert 1692). Aubert squirms under this forced dividualisation, while employing almost every trick in the book when it comes to 'Persecution and the Art of Writing'?

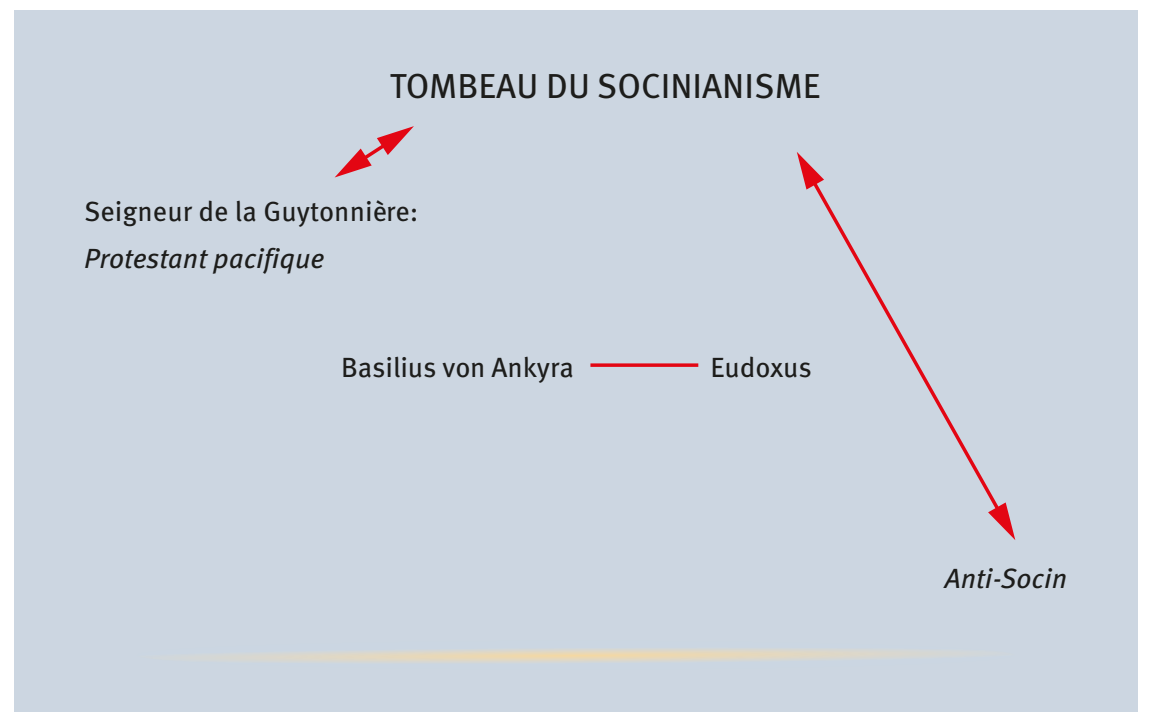

7 See the well-known work by Leo Strauss 1959. 


\section{Dividualisation}

A note on the idea of dividualisation may be useful at this point; I have already used the term repeatedly here to refer to the division of the persona of the author. The term is intended as counterpart to the term 'individualisation', not in order to deny the process of individualisation in the modern period in Europe, but to extend it and round it out. For what the idea of individualisation does not encompass, and even obscures, is the - occasional - internal pluralisation of the human being which occurs when persons are obliged to act differently on different levels (with multiple personae), or to adopt a stance in relation to positions of equal validity. As we have seen, this can lead to the formation of corresponding forms of text. I suggest the term 'dividualisation' to describe this phenomenon.

I have in mind here a theoretical discussion in anthropology, which (in response to Marcel Mauss' essay on the notion of the person as 'a category of the human mind') has developed around Melanesian forms of personhood. ${ }^{8}$ Since about 1990, Marilyn Strathern has written of the 'dividual personhood', while the anthropologist of visual art Alfred Gell used the term 'distributed personhood'. ${ }^{9}$ Strathern's meaning is that Melanesians typically interact as composite beings. They are the product of gifts, contributions or separations from others; they form a relational multiplicity, in relation to other persons. Where, from a Western standpoint, an observer might see only people exchanging objects, from their own point of view they are exchanging parts of themselves as persons. Gell's concern in this is to take the fact that personhood can be in a sense extended into objects, and to use it to deepen our understanding of art, not only Melanesian art, but also of phenomena in Western modern and contemporary art.

Two lessons can be drawn from this. The first is a certain scepticism as to the universal applicability of the concept of the individual. But the other is the possibility of adding to and broadening this concept, through the notion of 'dividualisation'. The anthropological description becomes especially interesting when it is related to Western contemporary life: not only is it possible to dispute the necessity of the link between Western contemporary life and individualisation, but as we have seen, it is also possible conversely to assert the relevance of non-Western dividual personhood for the contemporary West. Mark Mosko has recently suggested that a key to Christian conversion experiences can be found in the 'dividual person' (Mosko 2010). He also contrasts this idea with that of 'possessive individualism',

8 See as well the introduction to this section.

9 See Strathern 1988; Wagner 1994; Gell 1998; Fowler 2004; Ulbrich and Jancke 2005, 32ff.; Rampley 2005. 
a term coined by James Macpherson in 1962 in relation to the theories of Hobbes and Locke (Mosko 2013). Edward LiPuma goes on the offensive, suggesting that the model of dividual personhood could provide an impulse towards a concept of interpersonal freedom in contemporary societies, one which would include other people without tipping over into new forms of dominance (Li Puma 2000).

In using 'dividualisation' here as a term for a process of increasing internal pluralisation, in the sense of a habitual adoption of techniques to adapt to and withstand social and intellectual pluralisation and de-authorisation, I am not relying simply on importing Melanesian anthropology. We should not of course place too much weight on parallels with 'dividual persons' on the other side of the world; these parallels are weak, and are not much more than a stimulus to thought - but perhaps a useful one, as they allow us to see the other side not only of individualisation, but also of relational authorship. This is especially relevant when the networks, the relations - the multiplicity so to speak - shift to the interior of the single author.

\section{Fictional or real Greeks?}

It will of course be necessary to determine in each case exactly where the transitions lie between a merely epistemically intended dividualisation and dissolving of boundaries of the authorial persona, and the dividualisation of a real person as a strategy of dissimulation. Intellectuals such as Aubert de Versé were able without difficulty to pretend, against their true convictions, to reconvert to Catholicism, in order to travel to France to collect a pension, before returning to Holland and resuming their polemical activities. Such tactics reached their most extreme form in the case of Jean Aymon: Aymon was a Huguenot who wrote, for strategic reasons, a tract on the possible reconvergence of the Catholic and Protestant churches. In 1706 he gave out that he wished to reconvert, and obtained a passport to enter France, where he inveigled his way into the confidence of the Royal Librarian (Goldgar 1995, 174-80). He used this to purloin the manuscript of the Council of Jerusalem (1672) and remove it to Holland, intending to publish it in support of the Calvinist side in the dispute over the Perpetuité de la foy de l'eglise, concerning the continuity of the doctrine of the Eucharist from early Christian times onwards. ${ }^{10}$ This he did in 1708, with his Monumens Authentiques De La Religion Des Grecs, et De La Fausseté De Plusieurs Confessions De Foi Des Chrétiens Orientaux.

10 On this dispute see Zwierlein 2016, 124-42. 
While the pseudonyms adopted by Aubert and Le Clerc were still those of fictional Greeks such as 'Basilius of Ankyra' and 'Ambrosius Theographus', Aymon now introduced a new twist. In purloining documents from the Greek Orthodox Church, his tactic was to make real Greeks speak for his cause. As in the documentation battles between the confessions a hundred years earlier, for instance between Goldast and Gretser (Mulsow 2007, 145-90), it was considered most effective to let the 'res ipsa' speak - the documents themselves, which were not so mutable and assailable as the differing theological positions. The Monumens Authentiques was not concerned with the question of the Trinity, but with that of the Eucharist, the Communion. Here the battle lines were drawn somewhat differently. On the one side were the Jansenists around Antoine Arnauld and Pierre Nicole, who had taken the field to demonstrate to the Crown their otherwise disputed Catholic loyalties, and on the other side were the Huguenots around Jean Claude, who questioned whether the Transsubstantiation had been a doctrine of the early Church. Against him, Arnauld and Nicole arrayed their huge work on La Perpetuité de la foy, in which they claimed to show on the basis of authentic documents that precisely this doctrine had been maintained throughout the whole course of Christian tradition since earliest times.

But thanks to the purloined codex Aymon was now able to produce letters from the Patriarch of Alexandria and Constantinople, Kyrillos Loukaris, whose dogma in relation to the Eucharist appeared decidedly Protestant in tone (Aymon 1708, 1-199). ${ }^{11}$ This was in many ways more resounding as an argument than the 'Basilius' invented by Aubert, with his hypotheses of an early forgery of the Prologue to the Gospel of St John, for which he had no evidence. The network standing in this case behind the author, or rather publisher, Aymon, is a real if merely adapted one, that of the Patriarch Loukaris, a network with which Aymon was not personally acquainted at all, but which he had in a sense made his own, through his theft.

\section{Relational authorship}

Aymon's case, which was discussed with great ambivalence in Huguenot circles, also shows the reverse side of the pluralisation of personae and authorship: in situations such as this, not only could one author be several persons, several authors could also work on and refine a single text. We move here from dividualisation to relational authorship. Between 1710 and 1716 for instance, Aymon and a few friends who were also freethinkers were occupied with preparing for publication the manuscript of a work of the radical Enlightenment, Traité des

11 On Loukaris, see Hering 1968. 
trois imposteurs. This tract was inspired by Spinoza and reinforced with ideas critical of religion originating with Hobbes, Vanini and others. ${ }^{12}$ It is more of a compilation (an 'unfixed text'13) than a stand-alone piece of writing and was probably cobbled together in the years before 1700 by a student or admirer of Spinoza (possibly Jean-Maximilien Lucas or Jan Vroesen) as a hard-hitting atheist polemic intended for a wide readership.

The manuscript had lain for some years in the library of the Rotterdam Quaker Benjamin Furly, a friend of John Locke and of many freethinking, mostly Huguenot intellectuals. The text was then discovered by a group of men which included Jean Aymon, as well as Jean Rousset and the publishers Charles Levier and Thomas Johnson. They decided to publish it in print. This was a highly audacious plan, as even in liberal Holland the publication of an atheist text was an almost suicidal undertaking. Despite this, Aymon and Rousset improved somewhat the style and language of the text, making it perhaps rather more incisive, and Levier did in fact print the work in 1719 under the title Espirit des Spinoza, though in only a small number of copies, which were sold 'under the counter'.

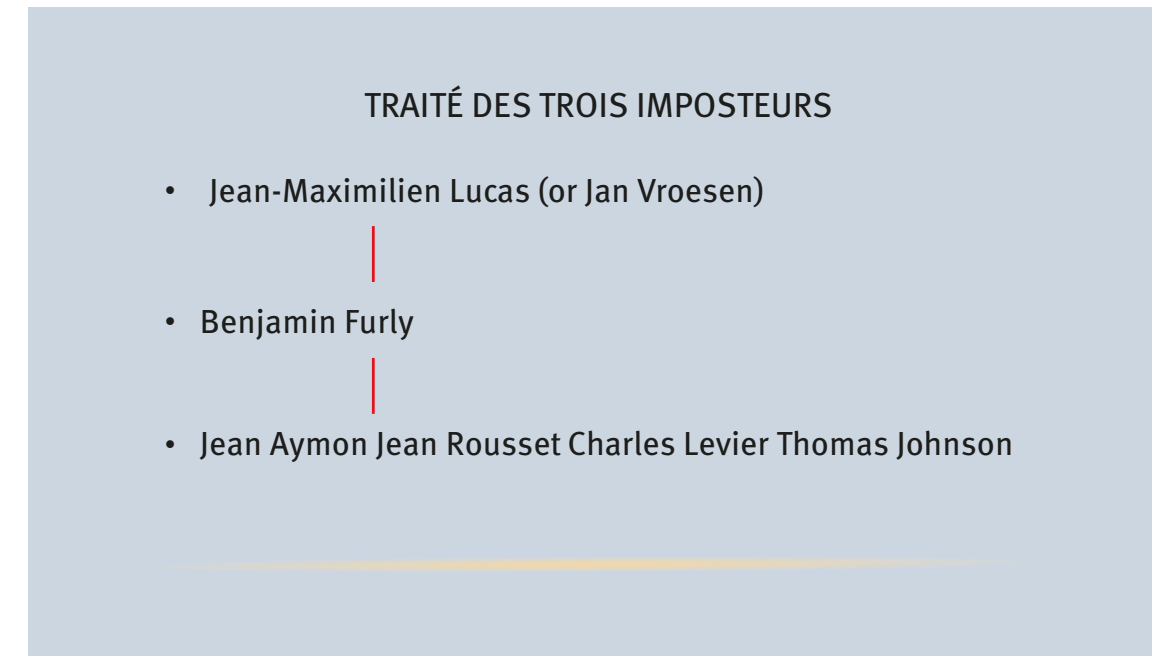

Authorship was therefore relationally shared out: many heads were involved. We should distinguish between the voices passively present in the text, through their

12 See the edition by Schröder 1994. On this work and its composition, see Berti, CharlesDaubert and Popkin 1996.

13 See Sabel and Bucher 2001. 
inclusion in the compilation, such as Hobbes, Spinoza and Vanini; the compiler (Lucas); and the relational authors in the actual sense - Aymon, Rousset and Levier, the producers of the final text. They are 'actually' relational in the sense that they knew each other and acted together, with collective intentionality.

How was it that Aymon, who was after all a defender of the Protestant cause, had a hand in this undertaking? One reason was surely that Aymon, like Aubert, was an adventurer who relished taking part in dangerous games of this kind. One would need to be some kind of daredevil to carry out an undercover commando operation on the library of the King of France - and to polish the style of an atheist pamphlet. Another reason may be that Aymon's dogmatic substance had begun to erode, as both a cause and a consequence of his changes of persona. To fight for the cause of the Protestants in Church politics was one thing, to believe in the letter of their dogma was another. There were in fact a number of intellectuals in the Netherlands who themselves no longer quite knew what to believe in any more. Whether they became sceptics, like Pierre Bayle, or simply concerned themselves with money and publishing success, like some booksellers, was no longer of prime importance. They found they had a taste for such little games as printing the text which was to become the most notorious work of the Enlightenment. Scholars have spoken of a 'grey identity' in relation to eroded intellectuals of this kind.

But what does Aymon's participation mean here in the light of our interest in dialogism and multiple pseudonymity? It shows us a complementary phenomenon: not an author who divides himself into several personae, but a text which has several progenitors. Interest in phenomena of multiple authorship has been aroused only in very recent times, with the questioning of the category of the author itself and the development of the theory of social networks. We need not necessarily speak of multiple authorship, but can instead, as I have here already, use the concept of 'relational authorship'. In doing so we join with the newer relational sociology ${ }^{14}$ of for instance Donati and Archer, who have explored the implications of the fact that in relations between persons - in networks - a variety of different reflexive references to a shared 'we' always play a part (Donati and Archer 2015). It is important to reconstruct historically such reflexive references, where groups of free-thinking intellectuals work together on writing a text, or views are pseudonymously advanced that can only be fully explained in relation to a shared cause. As I have stressed in the case of the Traite des trois imposteurs, 'actual' relationality and reflexive reference to a 'we' is only present where there is mutual acquaintance and reference by writers to each other.

14 See in general Emirbayr 1997. 
With 'unfixed' texts which grow slowly and are laid down layer by layer, as new authors extend, manipulate and rewrite the text, the question is more complicated. But whatever the case, we must ask: what kinds of connections in what kinds of networks were decisive? Were the connections strong or weak? What kinds of concern for what kind of 'we' were present? What is the collective intentionality of a militant confessional or post-confessional grouping? ${ }^{15}$

\section{Partially reflexive relationality}

Let us turn to a case where, as with the Traité, several people work on a single text, but where there is clearly no reflexivity in the narrower sense - that is, no personal acquaintance between those responsible for the final text. I remain here in the field of clandestine literature, and in the period around 1700. The text known as the Symbolum sapientiae is an openly atheist work, written in the years around 1690, which advances its arguments on the basis of a strict - and crude - naturalism. ${ }^{16}$ The author may have been a Wittenberg lawyer, Georg Michael Heber, but we do not know this for certain, and there are only a few indications of this. The text was distributed in only a small number of handwritten copies, and therefore had hardly any effect, despite its undoubted philosophical quality. The atheism it puts forward is of a sceptical kind. For its legally trained author, the burden of proof lies with those putting the case for the existence of God, while numerous objections can be brought to bear against it.

There are in fact a number of variants of this clandestine manuscript, which contain extensive additions to the text. Textual comparisons allow us to identify the anonymous author of these changes as Johann Georg Wachter, another radical author of the early German Enlightenment. Wachter must have obtained a copy of the Symbolum, perhaps in the years following 1710. Spinozist that he was, he identified so strongly with the text that he empathetically inscribed himself into it. Wachter's additions, which organically interpolate single words, half-sentences, and sometimes even whole passages into the flow of the argument, give the original text a somewhat differently nuanced orientation. The emphasis now lies rather more on a Socratic scepticism which is aware of its own limits, and on the hidden existence of the wise man who lives apart, unknown to society (Mulsow 2002, 241-7).

What has happened here? To what extent is the final clandestine text - a typical example of its kind - the product of relational authorship? Only in a

15 On collective intentionality see Searle 2011.

16 The edition edited by Canziani, Schröder and Socas 2000. See also Mulsow 2018, chapter 11. 
restricted sense, as a result of what I call clandestine 'networks over time' (Mulsow 2008; Mulsow 2014, 231). These are connections through which later radical, often isolated, authors align themselves with earlier thinkers who are often anonymous and therefore unknown to them by name, whose texts they acquire or transcribe and read intensively, so intensively that they sometimes even intervene in and extend the texts. There is reflexivity here in only one direction: the later partial author, in this case Wachter, identifies himself as part of a 'we' with the earlier author, Heber, but without the earlier author being able to respond, either being dead or knowing nothing of the later writer.

\section{Dividualisation and personae in natural law}

In conclusion let us examine how the different forms of dialogism, of dividualisation and of relational authorship relate to other types of division - in particular those motivated by natural law, which we also find around 1700, and which theorise the division of a person into several functions or roles. This is a line which extends from Samuel Pufendorf through Adam Smith to modern times (Kobusch 1993; Mulsow 2012, 58-79). Did the breaking down of boundaries between different schools of philosophy and religious confessions after 1685, in particular the boundaries surrounding Socinianism, lead to a blurring of the boundaries around the personhood of the author?

The relation between theological dialogism, as we find it in Le Clerc and Aubert, and dividuality based in natural law has not been remarked on up till now. But it is quite clear. In defence of his own freethinking books, Theodor Ludwig Lau, a student of Thomasius, invoked Pufendorf's concept of the persona moralis in the sense of a separation of roles. In his Meditationes philosophicae de Deo, Mundo, et Homine of 1717 Lau also saw himself, like the editor of the Epistolae theologicae, as a moderator, presenting various hypotheses for consideration, or as a theatre director, bringing different works to the stage without pronouncing in favour of any particular one. Where Le Clerc had spoken of speculative intellectual games within a small circle ('saepe se expertum in familiaribus confabulationibus'), Lau spoke similarly of proposals and suppositions 'merely problematically expressed', i.e. purely for the purposes of discussion (Lau 1719, preface). For Lau, reaction to pluralisation and retreat beyond the reach of legal or theological liability are two sides of the same coin, as they had been for some Renaissance freethinkers. That Pufendorf's social theory now offered a language in which to describe this was welcome, but not actually necessary for the formation of a writing strategy. 
Lau is certainly a compiler, like his slightly earlier counterpart in Berlin, Friedrich Wilhelm Stosch, an assiduous reader of Le Clerc's Epistolae theologicae. ${ }^{17}$ Both writers practised relational authorship only in the restricted sense that they put together different positions in the manner of a puzzle. This is undoubtedly dialogism, in the form of eclecticism, but is not explicitly presented as a mixture of opposing viewpoints. The dialogism emerges rather more implicitly; we notice it when it becomes clear that, with both Lau and Stosch, the eclectic mix of arguments from Locke, Gassendi, Spinoza, Toland or Thomasius is not really consistent. From a systematic philosophical standpoint each of these books is a disaster - bad amateur philosophy. But both authors insist that their texts are to be read more as reading notes, as a kind of Reader's Digest of positions which are naturalistic and critical of religion, and which seem to them worth discussing. Dialogism is to be seen here more as a retraction of claims to authorship, as a moderator's citation of the origins of the ideas presented. The actual dividuality of a figure such as Lau can be discerned rather in the distinction between a (supposedly) private Christian persona and an atheistic authorial persona, where this authorial persona is in fact the disclaimed one of the Reader's Digest compiler. It is only here that Lau employs Pufendorf's concept of different personae morales or roles, and argues that, even though as a 'weak' author he sets out a panorama of heterodox positions, as a private man he can still go to church like a good Christian (Lau 1719, § 2; see Mulsow 2012, 67ff.).

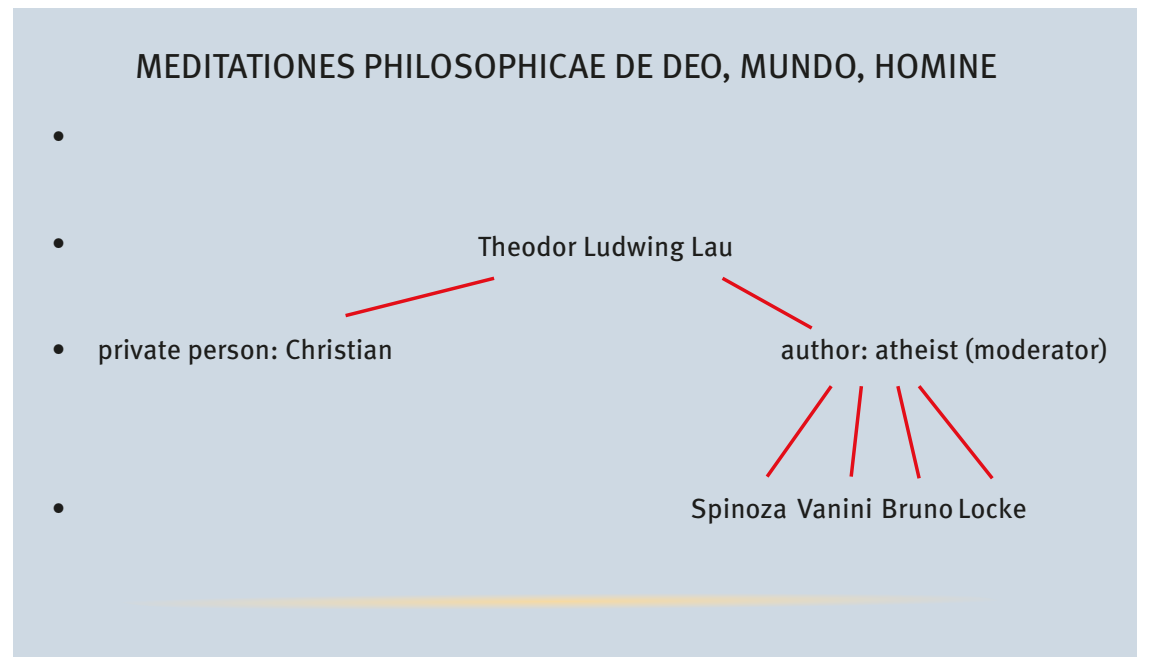

17 For Stosch's use of the Epistolae, see Mulsow 2018, chapter 13. 
That is as may be, but the connection was established at any rate between the division of roles, dividuality, eclecticism and dialogism. We should remember that dialogism in the context of scholarship does not produce a 'wild' polyphony, such as Bakhtin found in Rabelais' texts, but one which is highly controlled, tactical and precisely calibrated. This is how we should also see the dividuality of authors such as Le Clerc, Aubert or Lau: it is a very precisely considered dividuality that takes into account a hundred different circumstances, and encompasses all shades from the innocent to the criminal - as with Aymon.

This brings me to my conclusion. In the light of what we have reconstructed here, Søren Kierkegaard's strategy, in the 1840s, of making various pseudonyms in his writing speak against each other, in order to force the reader existentially to declare his position (Nun and Steward 2015), is actually an almost anachronistic readoption of the old pseudonymity-games from the confessional confrontations of the 17th century. As we know, in Either/Or, a fictional editor, 'Victor Eremita', presents first the papers of an aesthete 'A', also containing a 'Seducer's Diary' which is merely published by A, and then the papers and letters of an ethicist 'B', which respond to A. Other pseudonyms appear in other works by Kierkegaard: in Repetition, a recluse named 'Constantin Constantius' debates with a 'young person', while Fear and Trembling, which appeared at the same time, is supposedly written by a 'Johannes de Silentio'. The Concept of Anxiety is attributed to a 'Vigilius Haufniensis', the Philosophical Fragments to a 'Johannes Climacus'. It is true that the early Romantics around Friedrich Schlegel had been the first to lay the groundwork, with their theory of irony, for Kierkegaard's distancing techniques (Strohschneider-Kohrs 1960), and in the 19th century the pluralisation of the persona was no longer by any means the only possible way to respond to the pluralisation of world-views. In fact, we can say that a central aspect of the history of theory in the 18th century consisted in responding to the dilemma of absolute claims to truth in a pluralised epistemic situation, and using concepts of tolerance, eclecticism and the privatising of religion to offer ways of thinking which mark a new stage in the structure of social semantics. ${ }^{18}$

But for Kierkegaard these adjustments were unsatisfactory. He saw them as a levelling of Christianity, which was now merely 'tepidly' practised alongside bourgeois existence in a way that no longer had any bearing on the individual. He therefore strove for a renewed intensification of the claim to truth, no longer on a

18 For structural Shifts like this see above all Luhmann 1980-1995; for a 'communication reform' already around 1700 see Gierl 1997. 
dogmatic level, but conceived of as a commitment for the subjective existence. ${ }^{19}$ The result however was a reprise of some of the paradoxes of the early modern period. Perhaps this is why what Kierkegaard practised reminds us so strongly of Le Clerc's Epistolae theologicae. Kierkegaard's role as a protagonist of modern individualisation is undisputed. Should we not therefore also recognise the early adventurers of theological dialogism as protagonists of this kind? As protagonists of an individualisation through dividualisation? And should we not use the theories of relational authorship and of epistemic networks to pay closer attention to the networks around the texts, the networks around the authors and the networks in the authors?

I have not discussed here 'normal' networks between authors and their publishers, or authors and their correspondents, nor large-scale learned works such as Vincent Placcius' Theatrum anonymorum, which could not have been compiled without the collaboration of a large number of scholars - as Placcius himself says in his subtitle: 'from contributions and their comparison by learned men throughout Europe' (Mulsow 2007, 217-45). It is perhaps an irony of history that Placcius required a whole relational network of collaborators to trace those I am concerned with here: the multiple personae in Placcius' title engraving, shown as if dangling from the ceiling on a washing line.

I have been concerned here only with more 'acute' cases of relational authorship, where theologians faced with an accelerating pluralisation of world views felt they had no other option than to depict the whole complex network of mutually undermining positions in a single book; or where 'fluid' intellectuals tried to shake off their persecutors through tactical changes of pseudonym, while remaining on the lookout for new possibilities to reposition themselves; lastly, where underground authors had no sooner got their hands on a clandestine manuscript than they had added their own writing to it, and sometimes published it as well.

As we have seen, a relational analysis of these authors must address the whole complexity of the intellectual situation, for without it, these 'hommes pluriels' (Lahire 1998) would not have emerged. This may be a special case from the point of view of literary studies, but I would point out that it is often precisely the 'acute' cases, the cases where the extraordinary is the norm, the difficult cases, where the structures of a phenomenon are revealed with particular clarity.

19 See the contribution of Matthias Engmann to this section. 


\section{References}

Aubert de Versé, Noel. 1687. Le Tombeau du Socinianisme. Francfort: Arnaud.

Aubert de Versé, Noel. 1692. L'anti-socinien, ou nouvelle apologie de la foi catholique contre les sociniens et les calvinistes. Paris: Mazuel.

Aymon, Jean. 1708. Monuments authentiques de la religion des grecs et de la fausseteé de plusieurs confessions de foi des chrétiens orientaux. The Hague: Delo.

Bakhtin, Michail. 1984. Problems of Dostoevsky's Poetics. ed. and trans. Caryl Emerson. Minneapolis: University of Minnesota Press.

Barnes, Annie. 1938. Jean Le Clerc (1657-1736) et la République des lettres. Paris: Droz.

Berti, Silvia, Francoise Charles-Daubert and Richard H. Popkin (eds.). 1996. Heterodoxy, Spinozism, and Free Thought in Early-Eighteenth-Century Europe. Studies on the Traité des Trois Imposteurs. Archives internationales d'histoire des idées 148. Dordrecht: Kluwer Academic Publishers.

Bodin, Jean. 1857. Colloquium heptaplomeres de rerum sublimium arcanis abditis. ed. Ludwig Noack. Schwerin: Bärensprung.

Brogi, Stefano. 2012. Il ritorno di Erasmo. Critica, filosofia e religione nella 'République de Lettres'. Milano: Angeli.

Canziani, Guido, Winfried Schröder and Francisco Socas (eds.). 2000. Cymbalum mundi sive Symbolum sapientiae. Milano: Angeli.

Daugirdas, Kestutis. 2016. Die Anfänge des Sozinianismus. Genese und Eindringen des historisch-ethischen Religionsmodells in den universitären Diskurs der Evangelischen in Europa. Göttingen: Vandenhoek und Ruprecht.

Donati, Pierpaolo and Margaret S. Archer. 2015. The Relational Subject. Cambridge: Cambridge University Press.

Emirbayr, Mustafa. 1997. 'Manifesto for a Relational Sociology', American Journal of Sociology 103.2. 281-317.

Fowler, Chris. 2004. The Archeology of Personhood: An Anthropological Approach. London: Psychology Press.

Francken, Christian. 1593. Disputatio inter theologum et philosophum de incertitudine religionis christianae. Claudopoli.

Gawlick, Günter and Friedrich Niewöhner (eds.). 1996. Jeans Bodins 'Colloquium heptaplomeres'. Wolfenbütteler Forschungen 67. Wiesbaden: Harrassowitz.

Gierl, Martin. 1997. Pietismus und Aufklärung: Theologische Polemik und die Kommunikationsreform der Wissenschaft am Ende des 17. Jahrhunderts. Göttingen: Vandenhoek.

Goldgar, Ann. 1995. Impolite Learning. Community and Conduct in the Republic of Letters. New Haven: Yale University Press.

Gell, Alfred. 1998. Art and Agency: An Anthropological Theory. Oxford: Oxford University Press. Haase, Erich. 1959. Einführung in die Literatur des Refuge. Berlin: Duncker und Humblot.

Hazard, Paul. 2013. The Crisis of the European Mind. New York: New York Review of Books Classics. [French original: 1935]

Hempfer, Klaus W. 2002. Möglichkeiten des Dialogs. Struktur und Funktion einer literarischen Gattung zwischen Mittelalter und Renaissance in Italien. Stuttgart: Steiner.

Hering, Gunnar. 1968. Das ökumenische Patriarchat und europäische Politik 1620-1638. Wiesbaden: Steiner. 
Israel, Jonathan I. 2001. Radical Enlightenment. Philosophy and the Making of Modernity, 1650-1750. Oxford: Oxford University Press.

Kobusch, Theo. 1993. Die Entdeckung der Person. Metaphysik der Freiheit und modernes Menschenbild. Darmstadt: Wissenschaftliche Buchgesellschaft.

Kretzer, Helmut. 1975. Calvinismus und französische Monarchie im 17. Jahrhundert: Die politische Lehre der Akademien Sedan und Saumur, mit besonderer Berücksichtigung von Pierre Du Moulin, Moyse Amyraut und Pierre Jurieu. Berlin: Duncker und Humblot.

Lahire, Bernard. 1998. L'homme pluriel. Les ressorts de l'action. Paris: Nathan.

Lau, Theodor Ludwig. 1719. Meditationes. Theses. Dubia. Freystadi. [Reprinted ed. Martin Pott, Stuttgart 1992].

Le Clerc, Jean. 1681 [on the title page falsely: 1679]. Liberii a Sancto Amore Epistolae theologicae. Irenopoli: Typis Philalethianis.

Li Puma, Edward . 2000. Encompassing Others: The Magic of Modernity in Melanesia. Ann Arbor: University of Michigan Press.

Luhmann, Niklas. 1980-1995. Gesellschaftsstruktur und Semantik. 4 vols. Frankfurt am Main: Suhrkamp.

Mair, Meinhard. 2015. Erzähltextanalyse. Modelle, Kategorien, Parameter. Stuttgart: Ibidem-Verlag.

Marshall, John. 2006. John Locke, Toleration and Early Enlightenment Culture. Cambridge: Cambridge University Press.

Morman, Paul J. 1987. Noel Aubert de Versé. A Study in the Concept of Toleration. Lewiston, New York: Mellen Press.

Mosko, Mark S. 2010. 'Partible Penitents: Dividual Personhood and Christian Practice in Melanesia and the West', Journal of the Royal Anthropological Institute 16. 215-40.

Mosko, Mark S. 2013. 'Dividuals, Individuals, or Possessive Individuals?: Recent Transformations of North Mekeo Commoditization, Personhood, and Sociality'. In Engaging with Capitalism: Cases from Oceania, eds. Fiona Mccormack and Kate Barclay. Research in Economic Anthropology 33, London: Taylor and Francis. 167 -98.

Müller, Jan D., Wulf Österreicher and Friedrich Vollhardt (eds.). 2010: Pluralisierungen. Konzepte zur Erfassung der Frühen Neuzeit. Berlin: De Gruyter.

Mulsow, Martin. 2000. 'Pluralisierung'. In Oldenbourg Geschichte Lehrbuch: Frühe Neuzeit, ed. Anette Völker-Rasor, München: Oldenbourg, 303-7.

Mulsow, Martin. 2002. Moderne aus dem Untergrund. Radikale Frühaufklärung in Deutschland 1680-1720. Hamburg: Meiner.

Mulsow, Martin. 2005. 'The "New Socinians". Intertextuality and Cultural Exchange in Late Socinianism'. In Socinianism and Arminianism, eds. idem and Jan Rohls, Leiden: Brill, 49-78.

Mulsow, Martin. 2007. Die unanständige Gelehrtenrepublik. Wissen, Libertinage und Kommunikation in der Frühen Neuzeit. Stuttgart: Metzler.

Mulsow, Martin. 2008. 'Die Transmission verbotenen Wissens'. In Kulturen des Wissens im 18. Jahrhundert, ed. Ulrich Johannes Schneider, Berlin: De Gruyter, 61-80.

Mulsow, Martin. 2010. 'Exil, Kulturkontakt und Ideenmigration in der Frühen Neuzeit'. In Diskurse der Frühen Neuzeit, ed. Herbert Jaumann, Berlin: De Gruyter, 441-64.

Mulsow, Martin. 2012. Prekäres Wissen. Eine andere Ideengeschichte der Frühen Neuzeit. Berlin: Suhrkamp.

Mulsow, Martin. 2014. 'Radikaufklärung, moderate Aufklärung und die Dynamik der Moderne'. In Radikalaufklärung, eds. Jonathan I. Israel and idem, Berlin: Suhrkamp, 203-33. 
Mulsow, Martin. 2018. Radikale Frühaufklärung in Deutschland 1680-1720. 2 vols. Göttingen: Wallstein.

Nun, Katalin and Jon Stewart (eds.). 2015. Kierkegaard's Pseudonyms. Farnham/Burlington: Ashgate.

Pitassi, Maria Cristina. 1987. Entre croire et savoir. Le problème de la méthode critique chez Jean Le Clerc. Leiden: Brill.

Rampley, Matthew. 2005. 'Art History and Cultural Difference: Alfred Gell's Anthropology of Art', Art History 28.4. 524-51.

Ribard, Dinah. 2008. 'Le "petit maître de Saumur”: Tanneguy Le Fèvre et la socialisation de l'érudition protestante', Bulletin de la Société de l'Histoire du Protestantisme Français 154. 41-59.

Sabel, Barbara and André Bucher (eds.). 2001. Der unfeste Text. Perspektiven auf einen literatur- und kulturwissenschaftlichen Leitbegriff. Würzburg: Königshausen und Neumann.

Schmitz, Claudia. 2004. Rebellion und Bändigung der Lust: Dialogische Inszenierung konkurrierender Konzepte vom glücklichen Leben (1460-1540). Tübingen: Niemeyer.

Schröder, Winfried (ed.). 1994. Traktat über die drei Betrüger. Hamburg: Meiner.

Scribano, Maria Emanuela. 1980. Da Descartes a Spinoza. Percorsi della teologia razionale nel Seicento. Milano: Angeli.

Searle, John. 2011. Making the Social World. Oxford: Oxford University Press.

Simon, Jószef. 2008. Atheismus und radikale Reformation im frühneuzeitlichen Ostmitteleuropa. Wiesbaden: Harrassowitz.

Strathern, Marilyn. 1988. The Gender of the Gift. Problems with Women and Problems with Society in Melanesia. Berkeley: University of California Press.

Strohschneider-Kohrs, Ingrid. 1960. Die romantische Ironie in Theorie und Gestaltung. Tübingen. Niemeyer.

Strauss, Leo. 1959. Persecution and the Art of Writing. Glencoe: Free Press.

Ulbrich, Claudia and Gabriele Jancke (eds.). 2005. Vom Individuum zur Person: Neue Konzepte im Spannungsfeld von Autobiographietheorie und Selbstzeugnisforschung. Göttingen: Wallstein.

Van Miert, Dirk et al. 2017. Scriptural Authority and Biblical Criticism in the Dutch Golden Age. God's Word Questioned. Oxford: Oxford University Press.

Wagner, Roy. 1994. 'The Fractal Person'. In Big Men and Great Men: Personifications of Power in Melanesia, eds. Maurice Godelier and Malilyn Strathern, Cambridge: Cambridge University Press, 159-73.

Zwierlein, Cornel. 2016. Imperial Unknowns. The French and British in the Mediterranean, 1650-1750. Cambridge: Cambridge University Press. 
